\title{
PENGARUH MODEL PEMBELAJARAN APTITUDE TREATMENT INTERACTION) TERHADAP HASIL BELAJAR SISWA PADA MATERI SPLDV KELAS VIII SMP NEGERI 4 KENDARI
}

\author{
Mirnawati $^{(1)}$, La Ode Ahmad Jazuli ${ }^{2)}$, La Arapu ${ }^{3)}$ \\ ${ }^{1)}$ Alumni Jurusan Pendidkan Matematika, ${ }^{2)}$ Dosen Jurusan PendidikanMatematika FKIP \\ Universitas Halu Oleo Email: mwati859@gmail.com;ahmaddjazuli_laode@yahoo.com; \\ laarapu@gmail.com
}

\begin{abstract}
Abstrak
Penelitian ini dilaterbelakangi rendahnya hasil belajar matematika siswa. Populasi dalam penelitian ini adalah seluruh siswa kelas VIII SMP Negeri 4 Kendari tahun pelajaran 2018/2019 dengan jumlah siswa sebanyak 423 siswa yang terdistribusi pada 11 kelas paralel yaitu dari kelas VIII $_{1}$ sampai VIII 11 . Tekhnik pengambilan sampel secara simpel random. Data hasil penelitian dikumpulkan melalui instrumen Lembar observasi dan tes, instrumen tes digunakan untuk mengukur hasil belajar matematika siswa dalam bentuk essay. Berdasarkan hasil analisis data dan pembahasan diperoleh kesimpulan. 1) Hasil belajar matematis siswa yang daiajar dengan model pembelajaran konvensional diperoleh nilai rata-rata 73,77. 2) hasil belajarmatematis siswa yang diajar dengan menggunakan model pembelajaranATIdiperoleh nilai rata-rata77,09. 3) aktivitas siswa yang diajar dengan Model Pembelajaran ATI tergolong aktif; 4) Terdapat pengaruh yang signifikan penggunaan model pembelajaran ATI.
\end{abstract}

Kata Kunci: Pembelajaran, Interaction, matematika

\section{THE INFLUENCE OF MODEL LEARNING APTITUDE TREATMENT INTERACTION (ATI) AGAINST THE RESULTS OF STUDENT LEARNING ON THE MATERIAL SPLDV CLASS VIII SMP NEGERI 4 KENDARI}

\begin{abstract}
The study was backed by the poor results of learning math students. The population in this research is the whole grade VIII SMP Negeri 4 Kendari years lessons 2018/2019 with the number of students as much as 423 students distributed in parallel i.e. from grade 11 class VIII1 until VIII11. The dwarf simply random sampling. Data research results collected through observation Sheet instruments and tests, instrumen tests used to measure the results of learning math students in the form of essay. Based on the results of data analysis and discussion of the obtained conclusions. 1) mathematical learning Results of students who daiajar with conventional learning model obtained average value of 73.77. 2 mathematical learning) results of students taught using the ATI learning model obtained average value of 77.09. 3) activity of students who are taught by Active Learning Models qualifies as ATI; 4) there is a significant influence on the use of model learning of ATI.
\end{abstract}

Keywords: Learning, interaction,math. 


\section{Pendahuluan}

Pembelajaran matematika yang ada di tingkat satuan pendidikan dasar, menengah, hingga perguruan tinggi mampu mengembangkan kemampuan manusia dalam berpikir secara logis, sistematis, analisis, kritis dan kreatif. Semua kemampuan berpikir tersebut merupakan modal bagi manusia dalam bertindak dan mengambil keputusan secara tepat dan cepat sesuai situasi yang ada. Kemampuan berpikir logis membantu setiap orang untuk berpikir secara rasional dalam mengambil suatu keputusan, cara berpikir sistematis dan analitis belajar matematika membantu manusia terbiasa untuk memecahkan masalah secara sistematis sehingga seseorang menjadi terhindar dengan cara berpikir menarik kesimpulan secara "kebetulan", dan kemampuan berpikir kritis dan kreatif akan menunjang kesiapan manusia untuk bersaing dan berkompetisi dibidang ekonomi dan teknologi di era ini. Kita harus menyadari bahwa matematika itu penting baik sebagai alat bantu, sebagai ilmu (bagi ilmiyawan), sebagai pembimbing pola berfikir, maupun sebagai pembentuk sikap. (Yelli, 2013: 22).

Guru merupakan kunci dalam pembelajaran, karena guru menyusun desain pembelajaran, melaksanakan pembelajaran, dan menilai hasil belajar. Namun kenyataannya saat ini adalah guru lebih banyak menempatkan siswa sebagai objek dan bukan subjek didik. Ada persepsi umum yang sudah berakar dalam dunia pendidikan. Persepsi umum ini menganggap bahwa sudah merupakan tugas guru untuk mengajar dan menyodori siswa dengan muatan muatan informasi dan pengetahuan. Semua ini dapat berakibat terhadap rendahnya pencapaian hasil belajar siswa. Mencermati pentingnya pelajaran matematika maka optimalisasi pembelajaran matematika di dalam kelas menjadi sangatlah penting. Setiap siswa mampu memberdayakan semua potensi yang dimilikinya, mengembangkan inovasi dan kreativitasnya. Karena siswa sebagai individu yang potensial tidak dapat berkembang banyak tanpa bantuan guru dan masyarakat sekitar. Potensi ini hanya dapat digali dan dikembangkan serta di pupuk secara efektiv melalui strategi pendidikan dan pembelajaran yang terarah dan terpadu, yang dikelola secara serasi dan seimbang dengan memperhatikan pengembangan potensi peserta didik secara utuh dan optimal.

Aptitude Treatment Interaction (ATI) merupakan sebuah konsep yang berisikan sejumlah strategi pembelajaran yang sedikit banyaknya efektif digunakan untuk siswa tertentu sesuai dengan karakteristik kemampuannya. Untuk mencapai tujuan tersebut, ATI berupaya menemukan dan memilih sejumlah cara yang dijadikan sebagai perlakuan (treatment) yang tepat, yaitu treatment yang sesuai dengan perbedaan kemampuan (aptitude) siswa.

Hasil belajar merupakan salah satu indikator dari keberhasilan dalam melaksanakan proses pembelajaran. Ketercapaian hasil belajar dipengaruhi oleh berbagai unsur.

Menurut Sudjana (Jihad, 2012: 2) Belajar adalah suatu proses yang ditandai dengan adanya perubahan pada diri seseorang, perubahan sebagai hasil proses belajar dapat ditunjukkan dalam berbagai bentuk sebagai perubahan pengetahuan, pemahaman, sikap dan tingkahlaku, keterampilan, kecakapan, kebiasaan, serta perubahanaspek-aspek yang adaindividu yang belajar.

Pembelajaran merupakan suatu proses yang di tempuh oleh pendidik oleh pendidik untuk memberikan kemudahan pada peserta didik dalam upaya menata dan memberi nuangsa agar proses belajar dapat menjapai tujuan pembelajaran. Terdapat dua proses dalam suatu pembelajaran, yaitu proses belajar dan proses mengajar. Proses belajar dimana pelajar mempelajari sesuatu sedangkan didalam proses belajar mengajar, pengajar mengerjakan sesuatu. Pembelajaran akan efektif apabila terdapat keserasian atau keselarasan antara proses belajar yang dilakukan oleh pelajar dan proses mengajar yang dilakukan pengajar.

Jihad (2008: 14) mengatakan hasil belajar adalah kemampuan yang diperoleh anak setelah melakukan kegiatan belajar. Dalam kegiatan pembelajaran biasanya guru menetapkan tujuan belajar. Siswa yang berhasil dalam belajar adalah yang berhasil mencapai tujuan-tujuan pembelajaran. Untuk memperoleh hasil bealajar dilakukan evaluasi atau penilaian yang merupakan tindak lanjut atau cara untuk mengukur tingkat penguasaan siswa. Kemajuan prestasi belajar siswa tidak saja diukur dari tingkat penguasaan ilmu pengetahuan tetapi juga sikap dan keterampilan. Dengan demikian penilaian hasil belajar siswa mencakup segala hal yang dipelajari disekolah, baik itu mencakup pengetahuan sikap dan keterampilan. Hal ini sesuia dengan pendapat Hasibuan (2009: 6) yang menyatakan bahwa hasil belajar siswa mencakup perubahan pada tiga ranah siswa yaitu ranah 
kognitif (pengetahuan), ranah efektif (sikap), dan ranah psikomotorik (keterampilan).

Hasil belajar merupakan tolok ukur yang digunakan untuk menentukan tingkat keberhasilan siswa dalam mengetahui dan memahami suatu mata pelajaran, biasanya dinyatakan dengan nilai yang berupa huruf atau angka-angka. Hasil belajar dapat berupa keterampilan, nilai dan sikap setelah siswa mengalami proses belajar. Melalui proses belajar mengajar diharapkan siswa memperoleh kepandaian dan kecakapan tertentu serta perubahan-perubahan pada dirinya.

$$
\text { Model Pembelajaran Aptitude }
$$

Treatment Interaction (ATI). Secara substantif dan teoritik "Aptitude Treatment Interaction (ATI)" dapat diartikan sebagai suatu konsep atau pendekatan yang memiliki sejumlah strategi pembelajaran (treatment) yang efektif digunakan untuk individu tertentu sesuai dengan kemampuannya masing-masing. Ciri utama Model Pembelajaran Aptitude Treatment Interaction (ATI) ialah memberikan perhatian khusus kepada perbedaan setiap individu siswa, di mana dalam setiap kelompok siswa terdapat siswa yang berkemampuan tinggi, sedang, dan rendah. Aptitude Treatment Interaction (ATI) berisikan sejumlah strategi dengan mengelompokkan siswa berdasarkan kemampuannya, kemudian pada masing-masing kelompok diberikan perlakuan pembelajaran yang berbeda-beda sesuai dengan karakteristik cara belajar mereka. Tujuannya untuk menciptakan dan mengembangkan suatu model pembelajaran yang betul-betul peduli dan memperhatikan keterkaitan antara kemampuan (aptitude) seseorang dengan pengalaman belajar atau secara khas dengan metode pembelajaran (treatment). Cronbach berpendapat sebagaimana yang dikutip oleh Syafruddin Nurdin bahwa ATI merupakan sebuah pendekatan yang berusaha mencari dan menemukan perlakuan-perlakuan yang cocok dengan perbedaan kemampuan (Aptitude) siswa.

Jadi, model pembelajaran Aptitude Treatment Interaction (ATI) adalah suatu konsep atau model yang mencakup sejumlah strategi pembelajaran dengan mengembangkan kondisi pembelajaran yang efektiv terhadap siswa yang mempunyai tingkat kemampuan yang berbeda. Dari rumusan pengertian dan makna esensial yang telah dikemukakan diatas, terlihat bahwa model pembelajaran Aptitude Treatment Interaction (ATI) bertujuan untuk menciptakan dan mengembangkan suatu model pembelajaran yang betul-betul peduli dan memperhatikan antara kemampuan seseorang dengan pengalaman belajar atau khas dengan metode pembelajaran.

Proses belajar mandiri melalui modul didasari anggapan bahwa siswa akan lebih baik belajar dengan cara mereka sendiri yang terfokus langsung pada penguasaan tujuan khusus atau seluruh tujuan. Dalam belajar mandiri, menurut Wedemeyer (1983) yang dikutip dari Rusman, peserta didik yang belajar secara mandiri mempunyai kebebasan untuk belajar tanpa harus menghadiri pembelajaran yang diberikan guru/pendidik di kelas. Peserta didik dapat mempelajari pokok materi tertentu dengan membaca modul. (Rusman, 2011: 353)

Pertama, memberikan tugas membahas satu pokok bahasan yang diikuti sejumlah prosedur dan langkah-langkah tertentu. Hal ini dianalogkan degan memberikan problem solving kepada siswa. Kedua \& Ketiga, melalui self learning dengan modul dan sumber-sumber lainnya siswa ditugaskan melakukan pengumpulan informasi dan eksplorasi hal-hal yang berkaitan dengan pokok bahasan yang dipelajari. Kempat, setelah melalui fase satu, dua dan tiga diatas diharapkan siswa dapat memformulasikan penjelasan-penjelasan formulating and explanation. Artinya, siswa dapat menjelaskan apa-apa yang sudah dibaca, dipelajari dan dibahasnya melalui self learning. Kelima, mengadakan analisis terhadap langkahlangkah yang diterapkan diatas, lalu mencoba berusaha meningkatkan kepada pelaksanaan yang lebih baik untuk waktu-waktu mengajar berikutnya. Bagi kelompok siswa berkemampuan sedang diberikan juga perlakuan dengan memberikan modul, guru memberikan tugas membahas satu pokok bahasan yang diikuti sejumlah prosedur dan langkah-langkah tertentu. Hal ini dianalogkan dengan memberikan problem solving kepada siswa. Kedua \& Ketiga, melalui self learning dengan modul dan sumber-sumber lainnya siswa ditugaskan melakukan pengumpulan informasi dan eksplorasi hal-hal yang berkaitan dengan pokok bahasan yang dipelajari. Kempat, setelah melalui fase satu, dua dan tiga diatas diharapkan siswa dapat memformulasikan penjelasanpenjelasan formulating and explanation. Artinya, siswa dapat menjelaskan apa-apa yang sudah 
dibaca, dipelajari dan dibahasnya melalui self learning. Kelima, mengadakan analisis terhadap langkah-langkah yang diterapkan diatas, lalu mencoba berusaha meningkatkan kepada pelaksanaan yang lebih baik untuk waktu-waktu mengajar berikutnya.

Terakhir, bagi kelompok siswa yang mempunyai kemampuan yang rendah diberikan special treatment, yaitu berupa pembelajaran dalam bentuk re-teaching dan tutorial. Reteaching dan tutorial dipillih sebagai perlakuan khusus untuk kelompok ini, didasarkan pada pertimbangan bahwa mereka lambat dan sulit memahami serta menguasai bahan pelajaran. Oleh karena itu, kelompok ini harus mendapat apresiasi khusus dari guru, sehingga dengan cara demikian mereka dapat menguasai pelajaran yang diajarkan. Karena seperti diketahui bahwa salah satu tujuan pengajaran atau program tutorial adalah untuk memberikan bantuan dalam pembelajaran kepada siswa yang lambat, sulit dan gagal dalam belajar, agar dapat mencapai prestasi belajar secara optimal. Perlakuan ini diselenggarakan antara guru dan siswa pada kelompok rendah, yang diliputi oleh suasana berupa pembelajaran dalam bentuk re-teaching, tutorial, dan diskusi.

Model pembelajaran konvensional disebut juga model pembelajaran tradisional, yaitu model pembelajaran yang terpusat pada guru. Menurut Roestiyah (2001: 136) cara mengajar tradisional telah lama dijalankan dalam sejarah pendidikan ialah cara mengajar dengan ceramah. Sejak dahulu guru dalam usaha menularkan pengetahuannya pada siswa, ialah secara lisan atau ceramah. Cara ini kadangkadang membosankan dan kelemahan metode ceramah ini guru tidak mampu untuk mengontrol sejauhmana siswa telah memahami uraiannya. Apakah ketenangan/kediaman dalam mendengarkan pelajaran itu berarti mereka telah memahami pelajaran yang diberikan oleh guru.

Rusyan (1992: 176), menyatakan bahwa penyelenggaraan pembelajaran konvensional lebih menekankan kepada tujuan pembelajaran berupa penambahan pengetahuan. Jika dilihat dari tiga jalur modus penyampaian pesan pembelajaran, penyelenggaraan pembelajaran konvensional lebih sering menggunakan modus pemberian informasi (telling), ketimbang modus memperagakan (demonstrating) dan memberikan kesempatan untuk menampilkan unjuk kerja secara langsung (doing direct performance). Dalam perkataan lain, guru lebih sering menggunakan strategi atau metode ceramah dengan mengikuti urutan materi dalam kurikulum secara ketat. Penekanan aktivitas belajar lebih banyak pada buku teks, kemampuan mengungkapkan kembali isi buku teks tersebut. Jadi, pembelajaran konvensional kurang menekankan pada pemberian keterampilan proses (hands-on activities).

Adapun langkah-langkah pembelajaran konvensional adalah sebagai berikut: (1) Menyampaikan tujuan. Guru menyampaikan semua tujuan pelajaran yang ingin dicapai pada pelajaran tersebut. (2) Menyajikan informasi. Guru menyajikan informasi kepada siswa secara tahap demi tahap dengan metode ceramah. (3) Mengecek pemahaman dan memberikan umpan balik. Guru mengecek keberhasilan siswa dan memberikan umpan balik. (4)Memberikan kesempatan latihan lanjutan-Guru memberikan tugas tambahan untuk dikerjakan di rumah.

\section{Kajian Teori}

Menurut Sudjana (Jihad, 2012: 2) Belajar adalah suatu proses yang ditandai dengan adanya perubahan pada diri seseorang, perubahan sebagai hasil proses belajar dapat ditunjukkan dalam berbagai bentuk sebagai perubahan pengetahuan, pemahaman, sikap dan tingkah laku, keterampilan, kecakapan, kebiasaan, serta perubahan aspek-aspek yang ada individu yang belajar.

Belajar pada dasarnya adalah proses perubahan tingkah laku berikut adanya pengalaman. Pembentukan tingkah laku ini meliputi perubahan keterampilan, kebiasaan, sikap, pengetahuan, pemahaman dan apresiasi. Oleh sebab itu, belajar adalah proses aktif, yaitu proses mereaksi terhadap semua situasi yang ada disekitar individu. Belajar adalah suatu proses yang diarahkan pada suatu tujuan, proses berbuat melalui pengalaman. Belajar adalah proses melihat, mengamati, memahami sesuatu yang dipelajari. Apabila kita bicara tentang belajar, maka kita bercerita tentang cara mengubah tingkah laku seseorang atau individu melalui berbagai pengalaman yang ditempuhnya (Suprihatiningrum, 2016: 14).

Pembelajaran adalah serangkaian kegiatan yang melibatkan informasi dan lingkungan yang disusun secara terencana untuk memudahkan siswa dalam belajar. Lingkungan yang dimaksud tidak hanya berupa tempat ketika pembelajaran itu berlangsung, tetapi juga metode, media, dan peralatan yang diperlukan untuk menyampaikan informasi. Pembelajaran merupakan upaya yang dilakukan pendidik 
untuk membantu siswa agar dapat menerima pengetahuan yang diberikan dan membantu memudahkan pencapaian tujuan pembelajaran (Suprihatiningrum, 2016: 75).

Pembelajaran matematika adalah suatu proses atau kegiatan guru mata pelajaran matematika dalam mengajarkan matematika kepada para siswanya, yang didalamnya terkandung upaya guru untuk menciptakan iklim dan pelayanan terhadap kemampuan, potensi, minat, bakat, dan kebutuhan siswa tentang matematika yang amat beragam agar terjadi interaksi optimal antara guru dengan siswa serta antara siswa dengan siswa dalam mempelajari matematika. (Suyitno, 2004: 2).

Pembelajaran matematika adalah proses yang sengaja dirancang dengan tujuan untuk menciptakan suasan lingkungan yang memungkinkan siswa melaksanakan kegiatan belajar matematika dan proses tersebut berpusat pada guru mengajar matematika (Syafruddin dalam Soewandi, 2005: 25). Pada dasarnya rangkaian kegiatan yang dilaksanakan oleh guru sebagai pendidik dan siswa sebagai peserta didik dengan menggunakan sarana dan fasilitas pendidikan yang ada untuk mencapai tujuan yang telah ditetapkan dalam kurikulum.

Pembelajaran merupakan suatu proses yang di tempuh oleh pendidik oleh pendidik untuk memberikan kemudahan pada peserta didik dalam upaya menata dan memberi nuangsa agar proses belajar dapat menjapai tujuan pembelajaran. Terdapat dua proses dalam suatu pembelajaran, yaitu proses belajar dan proses mengajar. Proses belajar dimana pelajar mempelajari sesuatu sedangkan didalam proses belajar mengajar, pengajar mengerjakan sesuatu. Pembelajaran akan efektif apabila terdapat keserasian atau keselarasan antara proses belajar yang dilakukan oleh pelajar dan proses mengajar yang dilakukan pengajar.

\section{Hasil Belajar Matematika}

Jihad (2008: 14) mengatakan hasil belajar adalah kemampuan yang diperoleh anak setelah melakukan kegiatan belajar. Dalam kegiatan pembelajaran biasanya guru menetapkan tujuan belajar. Siswa yang berhasil dalam belajar adalah yang berhasil mencapai tujuan-tujuan pembelajaran. Untuk memperoleh hasil bealajar dilakukan evaluasi atau penilaian yang merupakan tindak lanjut atau cara untuk mengukur tingkat penguasaan siswa. Kemajuan prestasi belajar siswa tidak saja diukur dari tingkat penguasaan ilmu pengetahuan tetapi juga sikap dan keterampilan. Dengan demikian penilaian hasil belajar siswa mencakup segala hal yang dipelajari disekolah, baik itu mencakup pengetahuan sikap dan keterampilan. Hal ini sesuia dengan pendapat Hasibuan (2009: 6) yang menyatakan bahwa hasil belajar siswa mencakup perubahan pada tiga ranah siswa yaitu ranah kognitif (pengetahuan), ranah efektif (sikap), dan ranah psikomotorik (keterampilan).

Menurut Sudjana (2000: 3) hasil belajar adalah mencerminkan tujuan pada tingkat tertentu yang berhasil dicapai oleh anak didik (siswa) yang dinyatakan dengan angka atau huruf. Hasil belajar yang dimaksud tidak lain adalah nilai kemampuan siswa setelah evaluasi diberikan sebagai perwujudan dari upaya yang telah dilakukan selama proses belajar pembelajaran berlangsung.

$$
\text { Lebih }
$$

lanjut

DimyatidanMudjiono(2002:150-

151)menjelaskanbahwahasilbelajar

merupakanhalyang dapatdipandangdari duasisisiswadan darisisi guru.Dari sisi siswa,hasilbelajarmerupakantingkatperkembanga nmental yanglebihbaik bila dibandingkanpada saatsebelumbelajar.

Tingkatperkembanganmental tersebutterwujudpadajenis-jenisranah kognitif,afektif,danpsikomotor.Sedangkandari sisiguru,hasilbelajar merupakansaatterselesaikannya bahanpelajaran. Sedangkan Arikunto dalam Ngatini (2012: 153) mengatakan hasil belajar adalah hasil akhir setelahmengalami proses belajar, perubahan itu tampak dalam perbuatan yang dapatdiamati dan dapat diukur.

Hasil belajar merupakan tolok ukur yang digunakan untuk menentukan tingkat keberhasilan siswa dalam mengetahui dan memahami suatu mata pelajaran, biasanya dinyatakan dengan nilai yang berupa huruf atau angka-angka. Hasil belajar dapat berupa keterampilan, nilai dan sikap setelah siswa mengalami proses belajar. Melalui proses belajar mengajar diharapkan siswa memperoleh kepandaian dan kecakapan tertentu serta perubahan-perubahan pada dirinya.

Dari proses belajar diharapkan siswa memperoleh prestasi belajar yang baik sesuai dengan tujuan instruksional khusus yang ditetapkan sebelum proses belajar berlangsung. Salah satu cara yang dapat dilakukan untuk mengetahui tingkat keberhasilan belajar adalah menggunakan tes. Tes ini digunakan untuk menilai hasil belajar yang dicapai dalam materi pelajaran yang diberikan guru di sekolah. 
Dari kutipan diatas dapat disimpulkan bahwa hasil belajar merupakan tolok ukur atau patokan yang menentukan tingkat keberhasilan siswa dalam mengetahui dan memahami suatu materi pelajaran dari proses pengalaman belajarnya yang diukur dengan tes.

\section{Model Pembelajaran Aptitude Treatment Interaction (ATI)}

Secara substantif dan teoritik "Aptitude Treatment Interaction (ATI)" dapat diartikan sebagai suatu konsep atau pendekatan yang memiliki sejumlah strategi pembelajaran (treatment) yang efektif digunakan untuk individu tertentu sesuai dengan kemampuannya masing-masing. Ciri utama Model Pembelajaran ATI ialah memberikan perhatian khusus kepada perbedaan setiap individu siswa, di mana dalam setiap kelompok siswa terdapat siswa yang berkemampuan tinggi, sedang, dan rendah. ATI berisikan sejumlah strategi dengan mengelompokkan siswa berdasarkan kemampuannya, kemudian pada masing-masing kelompok diberikan perlakuan pembelajaran yang berbeda-beda sesuai dengan karakteristik cara belajar mereka. Tujuannya untuk menciptakan dan mengembangkan suatu model pembelajaran yang betul-betul peduli dan memperhatikan keterkaitan antara kemampuan (aptitude) seseorang dengan pengalaman belajar atau secara khas dengan metode pembelajaran (treatment). Cronbach berpendapat sebagaimana yang dikutip oleh Syafruddin Nurdin bahwa ATI merupakan sebuah pendekatan yang berusaha mencari dan menemukan perlakuan-perlakuan yang cocok dengan perbedaan kemampuan (Aptitude) siswa.

\section{Metode}

Jenis penelitian ini adalah eksperimen semu Penelitian ini melibatkan dua kelompok yakni kelompok eksperimen dan kelompok kontrol yang dipilih dengan menggunakan teknik purposive sampling yaitu secara acak.

Populasi dalam penelitian ini adalah seluruh siswa kelas VIII SMP Negeri 4 Kendari dengan jumlah siswa sebanyak 423 siswa yang terdistribusi pada 11 kelas paralel yaitu dari kelas $\mathrm{VIII}_{1}$ sampai $\mathrm{VIII}_{11}$.

Tabel 1

Daftar Jumlah Siswa Kelas VIII SMP Negeri 4 Kendari

Tahun Ajaran 2017/2018

\begin{tabular}{|l|l|c|c|}
\hline No & Kelas & JumlahSiswa & $\begin{array}{l}\text { Nilai Rata-rata } \\
\text { (US) Matematika }\end{array}$ \\
\hline 8 & VIII $_{8}$ & 38 & 67 \\
\hline 10 & VIII $_{10}$ & 38 & 67 \\
\hline \multicolumn{2}{|c|}{ Jumlah } & 76 & \\
\hline
\end{tabular}

Menurut sugiyono (2008: 81), sampel adalah bagian dari jumlah dan karakteristik yang dimiliki oleh populasi tersebut. Sampel dalam penelitian ini dipilih dengan menggunakan tekhnik purposive sampling. Untuk pemilihan sampelnya digunakan purposive sampling dimana pemilihan sampelnya secara sengaja dipilih dari banyak kelas untuk mengambil dua kelas yang berkemampuan relatif sama. Tekhnik sampling ini dipilih berdasarkan kemampuan yang relatif sama yang dilihat dari rat-ratadan varians nilai ulangan umum matematika pada semester genap siswa kelas VIII SMP Negeri 4 Kendari tahun ajaran 2018/2019. Adapun penentuan kelas yang digunakan sebagai kelas ekperimen dan kelas kontrol dilakukan secara acak (class random sampling).

Variabel yang digunakan dalam penelitian ini terdiri dari satu variabel bebas dan satu variabel terikat. Variabel bebas yaitu perlakuan berupa model pembelajaran Aptitude Treatment Interaction (ATI). Variabel terikat yaitu hasil belajar matematika siswa setelah dilakukan pembelajaran matematika dengan menggunakan model pembelajaran Aptitude Treatment Interaction (ATI).

Desain penelitian ini menggunakan desain penelitian Posttest Only Control Group Desain. Desain ini dalam bentuk sederhana, terdiri dari perlakuan eksperimen dan kontrol. Prosedurnya digambarkan sebagai berikut 
Tabel 2

Desain Penelitian

\begin{tabular}{|l|l|l|}
\hline & Perlakuan & Posttest \\
\hline $\mathrm{E}$ & $\mathrm{X}$ & $\mathrm{O}_{1}$ \\
\hline $\mathrm{K}$ & $\mathrm{Y}$ & $\mathrm{O}_{2}$ \\
\hline
\end{tabular}

(Setyosari, 2013: 187)

Keterangan :

E : Kelas Eksperimen

$\mathrm{K}$ : Kelas Kontrol

$\mathrm{X}$ : Perlakuan dengan menerapkan model pembelajaran Aptitude Treatment Interaction (ATI)

Y: Perlakuan dengan menerapkan model pembelajaran Konensional

$\mathrm{O}_{1}$ :Hasil posstest siswa setelah menerapkan model pembelajaran Aptitude Treatment Interaction (ATI) .

$\mathrm{O}_{2}$ :Hasil posstest siswa setelah menerapkan model pembelajaran konvensional.

Penelitian ini mempunyai instrument berupa lembar observasi dan tes hasil belajar matematika siswa.
Digunakan untuk mengukur tingkat aktivitas atau partisipasi guru dan siswa dalam pembelajaran matematika dengan menggunakan model pembelajaran Aptitude Treatment Interaction (ATI), dalam penelitian ini digunakan instrumen berupa lembar observasi yakni, lembar observasi untuk guru dan lembar observasi untuk siswa. Lembar observasi ini akan digunakan pada setiap pertemuan yaitu, sebanyak lima kali pertemuan.

Analisis lembar observasi untuk guru dan siswa menggunakan analisis persentase. Aturan konversinya dengan menggunakan rumus sebagai berikut:

$$
\begin{aligned}
& P(\%) \\
& =\frac{\text { jumlah skor hasil observasi }}{\text { jumlah skor maksimal }} \times 100 \%
\end{aligned}
$$

Tabel 3

Interpretasi Keterlaksanaan Pembelajaran

\begin{tabular}{|c|c|}
\hline $\begin{array}{c}\text { Persentase Keterlaksanaan } \\
\text { Pembelajaran }(\%)\end{array}$ & Kriteria \\
\hline $0 \%<$ persentase $\leq 20 \%$ & Sangat Kurang \\
\hline $20 \%<$ persentase $\leq 40 \%$ & Kurang \\
\hline $40 \%<$ persentase $\leq 60 \%$ & Sedang \\
\hline $60 \%<$ persentase $\leq 80 \%$ & Baik \\
\hline $80 \%<$ persentase $\leq 100 \%$ & Sangat Baik \\
\hline
\end{tabular}

Sumber: Widoyoko (2009: 242)

Validitas teoritik untuk sebuah instrumen evaluasi menunjuk pada kondisi bagi sebuah instrumen yang memenuhi persyaratan valid berdasarkan teori dan aturan yang ada. Sebelum tes tersebut digunakan, terlebih dahulu dilakukan validitas muka, validitas konstruk dan validitas isi instrumen oleh para ahli yang berkompeten. Validitas isi suatu alat evaluasi artinya ketepatan alat tersebut ditinjau dari segi materi yang dievaluasikan (Suherman dalam Aini, 2013: 33). Validitas isi dilakukan dengan membandingkan antara isi instrumen dengan materi pelajaran yang telah diajarkan, apakah soal pada instrumen penelitian sesuai atau tidak dengan indikator. Validitas muka dilakukan dengan melihat keabsahan susunan kalimat atau kata-kata dalam soal sehingga jelas pengertiannya dan tidak salah tafsir. Validitas konstruk merujuk pada pada kesesuaian antara hasil alat ukur dengan kemampuan yang ingin diukur. Jika instrumen tes dinyatakan sudah memenuhi validitas isi, validitas muka dan validitas konstruk kemudian diujicobakan kepada siswa di luar sampel penelitian, yaitu siswa kelas VIII SMP Negeri 4 Kendari yang telah menerima materi SPLDV. Uji coba validitas isi, validitas muka dan validitas konstruk untuk soal tes hasil belajar dilakukan oleh dua orang dosen dan satu orang guru matematika. Berdasarkan validasi secara teoritis yang telah dilakukan pada tanggal 17 September 2018, diperoleh kesimpulan bahwa instrumen soal tersebut telah layak dari segi materi, bahasa dan konstruksinya. Sehingga layak untuk dilanjutkan ke tahap validasi secara empirik (uji coba) untuk melihat validitas dan reliabilitas perangkat tes.

Setelah instrumen dinyatakan validitas secara teoritik, kemudian soal tes hasil belajar matematik tersebut diuji cobakan secara empiris kepada siswa kelas VIII SMP 4 Kendari. Tujuannya adalah untuk mengetahui tingkat 
reliabilitas dan validitas butir soal tes yang mana nantinya r-kritis ditentukan setelah melihat hubungan derajat bebas (jumlah siswa peserta tes (n) - 2) dengan taraf signifikansi 95\% pada tabel nilai pre sentil distribusi r. Selanjutnya uji validitas tiap item instrumen dilakukan dengan membandingkan $r_{\mathrm{XY}}$ dengan nilai kritis $r_{\text {tabel }}$ (nilai tabel). Tiap item tes dikatakan valid apabila pada taraf signifikasi $\alpha=0.05$ didapat $r_{\mathrm{XY}}>r_{\text {tabel }}$, sebaliknya jika $r_{\mathrm{XY}} \leq r_{\text {tabel }}$ maka butir tersebut gugur.

Tabel 4

Hasil Analisis Validitas Hasil Belajar Matematis

\begin{tabular}{|l|c|c|c|c|c|}
\hline \multicolumn{5}{|c|}{ Correlation } \\
\hline & Soal 1 & Soal 2 & Soal 3 & Soal 4 & Soal 5 \\
\hline Skor_total & & & & & \\
Pearson correlation & 0.543 & & & & \\
Sig. (2-tailed) & 0.001 & 0.842 & 0.717 & 0.609 & 0.723 \\
N & 34 & 0.000 & 0.000 & 0.010 & 0.000 \\
& & 34 & 34 & 34 & 34 \\
\hline
\end{tabular}

Reliabilitas yang berarti konsistensi adalah ciri umum dari suatu instrumen pengukuran dan penilaian pendidikan. Konsistensi tinggi skor instrumen dari suatu pengukuran ke pengukuran berikutnya merupakan ciri terpenting dari instrumen yang berkualitas tinggi (Ahiri dan Hafid, 2011: 243). Reliabilitas (reliability, kepercayaan) menunjuk pada suatu instrument dapat mengukur sesuatu yang akan diukur secara konsisten atau tidak berubah-ubah dari waktu ke waktu. Suatu instrument dapat dipercaya untuk digunakan sebagai alat pengumpul data

\section{Tabel 5}

Hasil Analisis Reliabilitas Posstest Hasil Belajar Matematis

\begin{tabular}{|c|c|}
\hline \multicolumn{2}{|c|}{ Reliability Statistics } \\
\hline Cronbach Alpha & N of Items \\
\hline 0.735 & 6 \\
\hline
\end{tabular}

Uji normalitas data dimaksudkan untuk mengetahui apakah data yang diperoleh berasal dari populasi yang berdistribusi normal atau tidak. Uji normalitas pada kelas eksperimen dan kelas kontrol menggunakan uji KolmogorovSmirnov dilakukan dengan menggunakan program IBM SPSS 21.

Uji homogenitas digunakan untuk mengetahui apakah kedua kelompok memiliki varians yang sama atau tidak. apabila kedua kelompok mempunyai varians yang sama maka jika telah diuji reliabilitasnya. Untuk mengukur reliabilitas instrument tes hasil belajar matematika digunakan rumus Alpha Cronbach karena rumus ini dapat dipergunakan baik untuk instrument yang jawabannya berskala (essai) maupun jika dikehendaki bersifat dikotomi.

Instrumen yang digunakan dalam penelitian ini adalah item-item yang valid dari seluruh item yang di uji panelis dan uji coba. Tes tersebut dengan maksud dalam penelitian ini jika mempunyai reliabilitas kategori tinggi. kedua kelompok tersebut homogen. Dalam pengujian ini untuk menguji apakah data mempunyai varians yang sama atau tidak digunakan uji Levene dengan bantuan SPSS 21 .

Data dalam penelitian ini setelah dilakukan uji normalitas dan uji homogenitas diperoleh bahwa data terdistribusi normal dan varians homogen, selanjutnya melakukan uji hipotesis dengan menggunakan rumus uji- $\mathrm{t}$ untuk dua kelompok data homogen, digunakan rumus Polled Varians 
Hasil

Berdasarkan hasil analisis data penelitian, berikut ini disajikan hasil-hasil yang diperoleh dari penelitian yang dilakukan ini.

Tabel 6.

Rekapitulasi Keterlaksanaan Skenario Pembelajaran yang Dilakukan Oleh Guru Menggunakan Model Pembelajaran Aptitude Treatment Interaction (ATI)

\begin{tabular}{|c|c|c|c|c|}
\hline \multirow{2}{*}{$\begin{array}{c}\text { Model } \\
\text { Pembelajaran }\end{array}$} & \multicolumn{3}{|c|}{ Aktivitas Guru } & \multirow{2}{*}{ Kriteria } \\
\cline { 2 - 5 } & Pertemuan & $\begin{array}{c}\text { Skor } \\
\text { Total }\end{array}$ & $\begin{array}{c}\text { Persentase } \\
(\%)\end{array}$ & \\
\hline $\begin{array}{c}\text { Aptitude } \\
\text { Treatment } \\
\text { Interaction } \\
\text { (ATI) }\end{array}$ & Pertama & 9 & $64,28 \%$ & Baik \\
\cline { 2 - 5 } & Kedua & 12 & $85,71 \%$ & Sangat Baik \\
\cline { 2 - 5 } & Ketiga & 12 & $85,71 \%$ & Sangat Baik \\
\cline { 2 - 5 } & Keempat & 14 & $100 \%$ & Sangat Baik \\
\hline
\end{tabular}

Skor Maksimal : 14

Berdasarkan hasil observasi di atas diperoleh bahwa tingkat kemampuan guru dalam melaksanakan pembelajaran Aptitude Treatment Interaction (ATI) menunjukkan hasil yang sangat baik. Pelaksanaan pembelajaran pada pertemuan pertama mencapai $64,28 \%$,

\section{Tabel 7}

Rekapitulasi Keterlaksanaan Skenario Aktivitas Siswa Pada Model Pembelajaran Aptitude Treatment Interaction (ATI)

\begin{tabular}{|c|c|c|c|c|}
\hline \multirow{2}{*}{$\begin{array}{c}\text { Model } \\
\text { Pembelajaran }\end{array}$} & \multicolumn{3}{|c|}{ Aktivitas Siswa } & \multirow{2}{*}{ Kriteria } \\
\cline { 2 - 4 } & Pertemuan & $\begin{array}{c}\text { Skor } \\
\text { Total }\end{array}$ & $\begin{array}{c}\text { Persentase } \\
(\%)\end{array}$ & Baik \\
\hline $\begin{array}{c}\text { Aptitude } \\
\text { Treatment } \\
\text { Interaction } \\
\text { (ATI) }\end{array}$ & Pertama & 29 & $60,41 \%$ & Baik \\
\cline { 2 - 5 } & Ketiga & 42 & $66,66 \%$ & Sangat Baik \\
\cline { 2 - 5 } & Keempat & 46 & $95,83 \%$ & Sangat Baik \\
\hline
\end{tabular}

Skor Maksimal : 48

Berdasarkan hasil observasi aktivitas siswa dalam pelaksanaan pembelajaran matematika menggunakan model pembelajaran Aptitude Treatment Interaction (ATI) pada materi SPLDV yang dilaksanakan sebanyak 4 pertemuan. Pertemuan pertama mencapai $60,41 \%$, pertemuan kedua mencapai $66,66 \%$, pertemuan ketiga mencapai $88 \%$ dan pertemuan keempat mencapai $95,83 \%$. Persentase rata-rata keterlaksanaan pembelajaran aktivitas siswa untuk seluruh pertemuan adalah $77,72 \%$. pertemuan kedua dan ketiga mencapai $85,71 \%$, dan pertemuan keempat mencapai $100 \%$. Persentasi rata-rata keterlaksanaan pembelajaran yang dilakukan guru untuk seluruh pertemuan adalah $83,92 \%$. 
Tabel 8.

Distribusi Posttest Siswa dengan Model Pembelajaran Aptitude Treatment Interaction (ATI) dan Model Pembelajaran Konvensional

\begin{tabular}{|c|c|c|c|c|c|}
\hline \multirow{2}{*}{ Interval } & \multirow{2}{*}{ Kategori } & \multicolumn{2}{|c|}{$\begin{array}{c}\text { Model pembelajaran } \\
\text { Aptitude Treatment } \\
\text { Interaction (ATI) }\end{array}$} & \multicolumn{2}{|c|}{$\begin{array}{c}\text { Pembelajaran } \\
\text { Konvensional }\end{array}$} \\
\cline { 3 - 6 } & & Frekuensi & $\begin{array}{c}\text { Persentase } \\
(\%)\end{array}$ & $\begin{array}{c}\text { Frekuensi } \\
\text { Persentase } \\
(\%)\end{array}$ \\
\hline$\geq 80$ & Sangat tinggi & 10 & 26 & 3 & 8 \\
\hline $60-79$ & Tinggi & 28 & 74 & 35 & 92 \\
\hline $40-59$ & Sedang & 0 & 2 & 0 & 0 \\
\hline $20-39$ & Rendah & 0 & 0 & 0 & 0 \\
\hline$<20$ & Sangat Rendah & 0 & 0 & 0 & 0 \\
\hline
\end{tabular}

Gambar 1

Grafik Distribusi Frekuensi Data Posttest

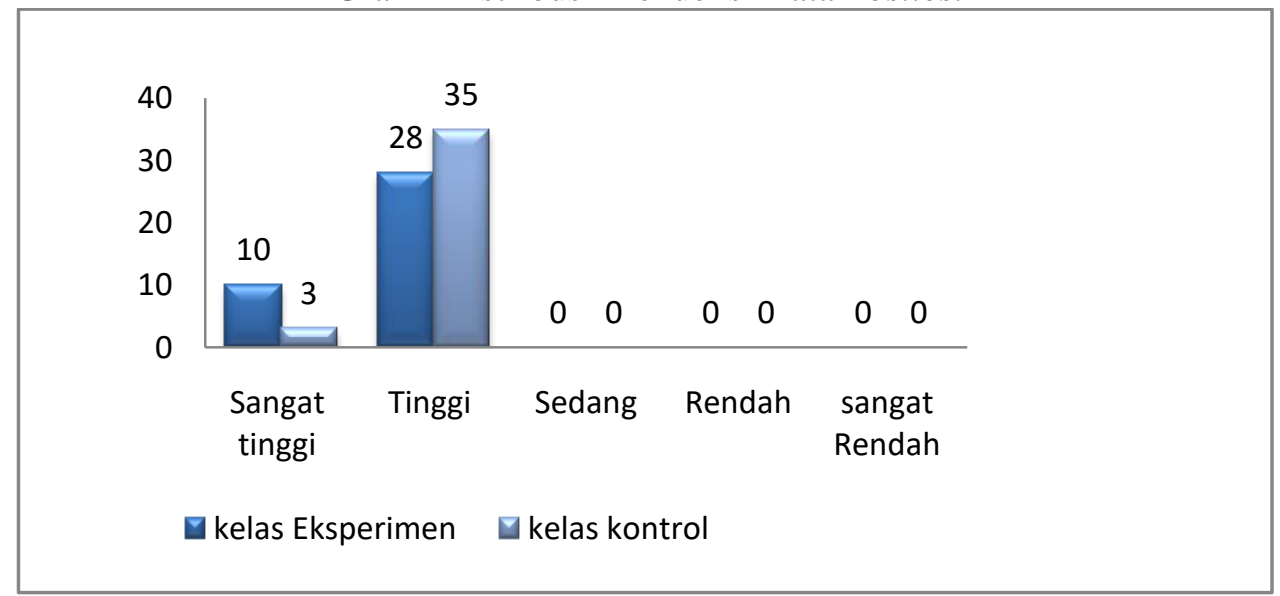

Dapat disimpulkan bahwa secara (ATI) lebih baik disbandingkan siswa yang klasikal rata-rata hasil belajar siswa yang pembelajarannya menggunakan model pembelajarannya menggunakan model pembelajaran konvensional.

pembelajaran Aptitude Treatment Interaction

Tabel 9.

Hasil Analisis Deskriptif Hasil Belajar Matematis Siswa Kelas Eksperimen dan Kelas Kontrol

\begin{tabular}{|c|c|c|}
\hline StatistikDeskriptif & KelasEksperimen & KelasKontrol \\
\hline Rata-rata & 77,09 & 73,77 \\
\hline $\mathrm{N}$ & 38 & 38 \\
\hline StandarDeviasi & 5,019 & 3,658 \\
\hline VariansSampel & 25,189 & 13,380 \\
\hline NilaiMaksimum & 88,00 & 82,00 \\
\hline Nilai Minimum & 60,00 & 65,00 \\
\hline Modus & 73,00 & 72,00 \\
\hline Median & 76,84 & 73,68 \\
\hline Skewnes & $-0,451$ & 0,208 \\
\hline
\end{tabular}

Hasil analisis deskriptif pada kelas eksperimen sebagaimana disajikan pada tabel 4.4 diperoleh nilai terendah 60,00 dan nilai tertinggi 88,00 , nilai rata-rata 77,09 , median atau nilai tengah 76,84, modus atau nilai yang sering muncul yaitu 73,00, standar deviasi 5,019, varians 25,189 dan skewness -0,451. Hasil analisis deskriptif pada kelas kontrol diperoleh nilai terendah 65,00 dan nilai tertinggi 82,00, nilai rata-rata 73,77 , median atau nilai tengah 
73,68 , modus atau nilai yang sering muncul yaitu 72,00, standar deviasi 3,658, varians 13,380 dan skewness 0,208.

Uji normalitas digunakan untuk mengetahui apakah data kemampuan pemecahan masalah matematis kedua kelas berdistribusi normal atau tidak. Untuk menguji apakah data berdistribusi normal atau tidak digunakan statistik uji normalitas dengan rumus Kolmogorov-Smirnov, menggunakan program SPSS 21. Hasil perhitungannya disajikan dalam tabel 4.5 berikut:

Tabel 10.

Hasil Analisis Statistik Uji Normalitas Data Hasil Belajar Matematis Siswa Kelas Eksperimen dan

Kelas Kontrol

One-Sample Kolmogorov-Smirnov Test

\begin{tabular}{|l|l|r|r|}
\hline \multicolumn{2}{|l|}{} & Kelas Ekperimen & Kelas Kontrol \\
\hline $\mathrm{N}$ & 38 & 38 \\
\hline \multirow{2}{*}{ Normal Parameters } & Mean & 77,09 & 73,77 \\
\cline { 2 - 4 } & & 5,019 & 3,658 \\
\hline \multirow{2}{*}{$\begin{array}{l}\text { Most Extreme } \\
\text { Differences }\end{array}$} & Absolute & 0,134 & 0,106 \\
\cline { 2 - 4 } & Positive & 0,095 & 0,106 \\
\cline { 2 - 4 } & Negative & $-0,134$ & $-0,096$ \\
\hline \multicolumn{2}{|l|}{ Kolmogorov-Smirnov Z } & 0,829 & 0,653 \\
\hline Asymp. Sig. (2-Tailed) & 0,498 & 0,787 \\
\hline
\end{tabular}

Uji homogenitas digunakan untuk mengetahui apakah data mempunyai varians yang sama (homogen) atau tidak. Untuk menguji apakah data mempunyai varians yang sama atau

Tabel 11.

Hasil Analisis Uji HomogenitasTest of Homogeneity of Variances

\begin{tabular}{|l|l|l|l|}
\hline Levene Statistic & df1 & df2 & Sig. \\
\hline 2,673 & 1 & 74 & 0,106 \\
\hline
\end{tabular}

Berdasarkan hasilAnalisis Uji kelompok mempunyai data yang homogen. Hal HomogenitasTest of Homogeneity of ini menunjukkan bahwa data hasil belajar Variancesbahwa nilai signifikan statistik uji matematis siswa kedua kelompok yaitu yang Levene adalah 0,106. Nilai signifikan ini lebih diajar dengan menggunakan model pembelajaran besar dari taraf nyata signifikan 0,05 (nilai sig.= Aptitude Treatment Interaction (ATI)dan $0,106>\alpha=0,05)$ sehingga dapat disimpulkan pembelajaran konvensional memiliki varians terima $\mathrm{H}_{0}$, artinya bahwa varians kedua yang homogen.

Tabel 12.

Hasil Analisis Uji Hipotesis dengan SPSS Independent Samples Test

\begin{tabular}{|c|c|c|c|c|c|c|}
\hline \multicolumn{7}{|c|}{ T-Test For Equality Of Means } \\
\hline \multirow[b]{2}{*}{$\mathrm{T}$} & \multirow[b]{2}{*}{ Df } & \multirow{2}{*}{$\begin{array}{l}\text { Sig. (2- } \\
\text { Tailed) }\end{array}$} & \multirow{2}{*}{$\begin{array}{c}\text { Mean } \\
\text { Difference }\end{array}$} & \multirow{2}{*}{$\begin{array}{l}\text { Std. Error } \\
\text { Difference }\end{array}$} & \multicolumn{2}{|c|}{$\begin{array}{l}\text { 95\% Confidence Interval } \\
\text { Of The Difference }\end{array}$} \\
\hline & & & & & Lower & Upper \\
\hline 3,281 & 74 & 0,002 & 3,342 & 1,019 & 1,313 & 5,372 \\
\hline 3,281 & 67,081 & 0,002 & 3,342 & 1,019 & 1,309 & 3.375 \\
\hline
\end{tabular}

Berdasarkan hasil analisis uji-t diperoleh $\mathrm{t}_{\text {hitung }}=3,281>\mathrm{t}_{\text {tabel }}=1,665$ atau nilai $\frac{\operatorname{Sig}(2 \text {-tailed })}{2}=\frac{0,002}{2}=0,001<0,05$, maka $\mathrm{H}_{0}$ ditolak. Dengan ditolaknya $\mathrm{H}_{0}$, maka dapat disimpulkan bahwa Terdapat pengaruh yang signifikan yang diajar dengan model pembelajaran Aptitude Treatment Interaction (ATI) terhadap hasil belajar matematis siswa.

\section{Pembahasan}

Aktivitas siswa selama proses pembelajaran dengan menggunakan model pembelajaran Aptitude Treatment Interaction (ATI)mengalami peningkatan setiap pertemuan. Hal ini karena model pembelajaran Aptitude Treatment Interaction (ATI)dalam pembelajaran 
matematika bertujuan menciptakan suasana pembelajaran agar siswa memperoleh pengalaman dalam menemukan sesuatu yang baru melalui proses pembelajaran, yang tujuannya adalah membantu mengembangkan aktivitas dan berpikir matematis siswa secara serempak dalam meningkatkan hasil belajar matematis siswa.

Pelaksanaan pembelajaran matematika menggunakan model pembelajaran Aptitude Treatment Interaction (ATI) yang dilakukan oleh peneliti di kelas eksperimen pada materi SPLDV, pada pertemuan pertama presentase ini belum dapat dikatakan aktif. Keadaan ini disebabkan karena sebagian siswa masih dalam tahap penyesuaian dengan pemberian LKPD yang merupakan situasi yang baru bagi mereka. Selain itu sebagian siswa masih kurang memahami materi karna tiap kemampuan siswa yang berbeda-beda, sehingga dalam memberikan perlakuan kelompok berjalan kurang baik. Kelompok siswa juga belum mampu mengkomunikasikan penyelesaian LKPD yang diberikan, terutama pada kelompok rendah. Beberapa Siswa kelompok tinggi kelompoknya cenderung memilih untuk berkerja sendiri dalam menyelesaikan LKPD yang diberikan. Sedangkan bagi kelompok yang berkemampuan sedang memilih untuk bekerjasama dengan kelompoknya, kelompok ini lebih cenderung banyak berkomunikasi sesama siswa.

Pelaksanaan pembelajaran pada pertemuan kedua dan pertemuan-pertemuan selanjutnya sudah mulai membaik. Meskipun pada pertemuan kedua, peneliti tidak menyampaikan tujuan pembelajaran yang akan dicapai dalam pembelajaran. Pada kegiatan inti, peneliti masih menyesuaikan model pembelajaran yang dilakukan. Pada kegiatan penutup, guru tidak memberikan pekerjaan rumah (PR) berkaitan dengan kondisi waktu yang terbatas. Sementara pada pertemuan ketiga peneliti lalai dalam memeriksa kehadiran siswa dan tidak penyampaian tentang materi/kegiatan pembelajaran berikutnya mengenai model pembelajarn Aptitude Treatment Interaction (ATI). Pada pertemuan keempat atau pertemuan terakhir sudah sangat baik dan sudah terlakasana. Dimana, pada kegiatan pendahuluan sampai penutup semua kegitan pembelajaran dapat terlaksana. Kekurangan-kekurangan yang dilakukan guru pada proses pembelajaran di kelas eksperimen, disebabkan karena guru masih berusaha menyesuaikan diri dengan kondisi pembelajaran yang baru dan karakteristik siswa yang beragam. Oleh karena itu, untuk memperbaikinya peneliti lebih menyesuaikan langkah-langkah pembelajaran dengan waktu yang dibutuhkan dan lebih mencoba mengenal dan memahami karakter siswa yang beragam.

Berdasarkan hasil analisis deskriptif dari data yang diperoleh melalui tes hasil belajar matematis siswa, pada posttest kelas eksperimen diperoleh nilai rata-rata yang lebih tinggi dari pada nilai rata-rata yang diperoleh pada posttest kelas kontrol. Berdasarkan nilai rata-rata, maka hasil belajar matematis siswa kelas eksperimen lebih tinggi dari hasil belajar matematis siswa kelas kontrol. Hal ini mengindikasikan bahwa dari indikator rata-rata, model pembelajaran Aptitude Treatment Interaction (ATI) mampu memberikan pengaruh yang cukup baik dalam meningkatkan hasil belajar matematis siswa. Dari indikator keragaman data (varians), data posttest kelas eksperimen memiliki Dari segi keragaman data (varians), kelas eksperimen mempunyai varians yang lebih besar dari kelas kontrol, yang berarti bahwa hasil belajar matematis siswa pada kelas eksperimen lebih beragam dibandingkan dengan hasil belajar matematis siswa pada kelas kontrol. Dari indikator Skewness (kemiringan), kelas eksperimen memiliki lebih banyak siswa yang hasil belajarnya di atas rata-rata, sedangkan pada kelas kontrol memiliki lebih banyak siswa yang hasil belajarnya di bawah rata-rata. Median (nilai tengah) dan nilai yang sering muncul (modus) dari hasil posttest kelas eksperimen lebih tinggi dibandingkan dengan hasil pada posttest kelas kontrol. Deskripsi hasil belajarmatematissiswa pada kelas eksperimen dan kelas kontrol terlihat jelas bahwa hasil belajar siswa kelas eksperimen lebih baik jika dibandingkan kelas kontrol, baik dilihat dari nilai maksimum, minimum, rata-rata, median, modus, standar deviasi, varians danskewnessnya.

Berdasarkan teori yang ada model pembelajaran Aptitude Treatment Interaction (ATI) adalah suatu konsep atau model yang mencakup sejumlah strategi pembelajaran dengan mengembangkan kondisi pembelajaran yang efektif terhadap siswa yang mempunyai tingkat kemampuan yang berbeda. Dari rumusan pengertian dan makna esensial yang telah dikemukakan, terlihat bahwa model pembelajaran Aptitude Treatment Interaction (ATI) bertujuan untuk menciptakan dan mengembangkan suatu model pembelajaran yang betul-betul peduli dan memperhatikan antara kemampuan seseorang dengan 
pengalaman belajar atau khas dengan metode pembelajaran. Model pendekatan Aptitude Treatment Interaction (ATI) yang dikembangkan dalam penelitian ini terdiri dari empat tahapan, yaitu (1) Treatment Awal, treatment awal pada siswa ini dengan menentukan dan menetapkan klasifikasi kelompok siswa berdasarkan tingkat kemampuan (aptitude/ability).

Pengelompokkan siswa, pengelompokkan siswa yang didasarkan pada treatment awal. Siswa di dalam kelas diklasifikasikan menjadi tiga kelompok yang terdiri dari siswa yang berkemampuan tinggi, sedang, dan rendah. (3) Memberikan perlakuan (Treatment), kepada masing-masing kelompok diberikan perlakuan (treatment) yang dipandang cocok/sesuai dengan karakteristiknya. Berkaitan dengan hal tersebut, maka dapat dikatakan bahwa model pembelajaran Aptitude Treatment Interaction (ATI) memiliki potensi untuk meningkatkan hasil belajar matematis siswa. Hal ini tentunya akan berdampak pada peningkatan mutu hasil belajar matematika siswa yang sangat diharapkan dalam pendidikan.

\section{Simpulan Dan Saran Simpulan}

Berdasarkan hasil penelitian dan pembahasan dalam penelitian ini, maka dapat dikemukakan beberapa kesimpulan sebagai berikut :

1. Deskripsi hasil belajar matematis siswa kelas VIII 8 SMP Negeri 4 Kendari yang daiajar dengan model pembelajaran konvensional pada materi SPLDV diperoleh nilai rata-rata 73,77 ; standar deviasi 3,658 ; varians 13,380; median 73,68; modus 72,00 ; nilai minimum 65,00 dan maksimum 82,00, serta skewness 0,208.

2. Deskripsi hasil belajar matematis siswa kelas VIII 10 SMP Negeri 4 Kendari yang diajar dengan menggunakan model pembelajaran Aptitude Treatment Interaction (ATI) pada pokok bahasan SPLDV diperoleh nilai rata-rata77,09; standar deviasi 5,019; varians 25,189; median 76,84; modus 73,00; nilai minimum 60,00, maksimum 88,00 serta skewness $-0,451$.

3. Deskripsi aktivitas siswa yang diajar dengan Model Pembelajaran Aptitude Treatment Interaction (ATI) kelas VIII SMP Negeri 4 Kendari tergolong aktif. Secara keseluruhan persentase tingkat aktivitas siswa pada 4 kali pertemuan berturut-turut adalah
$60,41 \%, 66,66 \%, 88 \%$, dan 95,83\%, persentase ini terkategori sangat baik dengan rata-rata persentase keaktifan siswa yang mengikuti pembelajaran dengan model pembelajaran Aptitude Treatment Interaction (ATI).

4. Terdapat pengaruh model pembelajaran Aptitude Treatment Interaction (ATI) Pada Materi SPLDV terhadap hasil belajar matematika siswa kelas VIII SMP Negeri 4 Kendari.

5.

Saran

Berdasarkan hasil penelitian ini, maka peneliti mengemukakan saran-saran sebagai berikut:

1. Kepada para guru yang mengajar mata pelajaran matematika pada materi SPLDV dapat menggunakan model pembelajaran Aptitude Treatment Interaction (ATI) sebagai salah satu alternatif dalam pembelajaran matematika untuk mengoptimalkan hasil belajar matematika siswa.

2. Seorang guru harus dapat memperhatikan keadaan siswa dalam menerapkan model pembelajaran Aptitude Treatment Interaction (ATI), karena tidak setiap siswa dapat dengan mudah menyesuaikan diri dalam mengembangkan hasil belajar matematis siswa. Selain itu pembagian kelompok oleh guru harus dilakukan secara heterogen agar dapat terjalin kerjasama yang baik dalam suatu kelompok.

3. Bagi peneliti yang hendak menggunakan model pembelajaran Aptitude Treatment Interaction (ATI) sebaiknya menggunakan teknik tertentu untuk memanfaatkan waktu dengan baik sehingga pembelajaran dengan menggunakan model pembelajaran Aptitude Treatment Interaction (ATI) dapat dilaksanakan dengan maksimal.

\section{Daftar Pustaka.}

Ahiri, J dan A. Hafid. 2011. Evaluasi Pembelajaran dalam Konteks KTSP. Humaniora : Bandung. 
Aini, I.N.2013.Meningkatkan literasi matematika siswa melalui pendekatan keteralampilan Matematis. Studi Kuasi eksperimen pada siswa madrasah tsanawiyah. Tesis Pada SPS UPI Bandung: tidak diterbitkan.

Arikunto, Suharsimi. 2002. Dasar - Dasar Evaluasi Pendidikan. Jakarta : Bumi Aksara.

Aqib, Zainal, dkk. 2011. Penelitian Tindakan Kelas Untuk Guru, SMP, SMA, SMK. Bandung: Yrama Widya.

Jihad, dkk. 2013. Evaluasi Pembelajaran. Yogyakarta : Multi Pressindo.

Roestiyah. 2001. Strategi Belajar Mengajar. Jakarta: Rineka Cipta.
Setyosari. 2013.Metode Penelitian Pendidikan dan Pengembangan.Jakarta : Kencana Prenadamedia Group.

Soewandi, A. M. Slamet. 2005. Perspektif Pembelajaran Berbagai Bidang Studi. Yogyakarta: Universitas Sanata Dharma.

Suprihatiningrum, Jamil. 2016. Strategi Pembelajaran. Jogjakarta : Ar-Ruzz Media.

Yelli dkk, Meningkatkan Kemampuan Pemecahan Masalah Siswa Sekolah Menengah Atas melalui Pembelajaran Kooperatif Tipe JigSaw, vol.17 no.2 2012, h.22, (http://www.jpmipa.fpmipa.upi.edu/jurnalterbaru-volume-17-nomor-2-oktober2012/ 